\title{
Molecular cloning, expression, sequence analysis and in silico comparative mapping of trehalose 6-phosphate gene from Egyptian durum wheat
}

\author{
Ayman A. Diab ${ }^{1 \star}$, Ahmed M. K. Nada ${ }^{2}$ and Ahmed Ashoub ${ }^{3}$ \\ ${ }^{1}$ Molecular Markers and Genome Mapping Department, Agricultural Genetic Engineering Research Institute (AGERI), \\ Agricultural Research Center (ARC), Giza, 12619-Egypt. \\ ${ }^{2}$ Plant molecular Biology department, Agricultural Genetic Engineering Research Institute (AGERI), Agricultural \\ Research Center (ARC), Giza, 12619-Egypt. \\ ${ }^{3}$ Nucliec acid and protein structure department Center (ARC), Agricultural Genetic Engineering Research Institute \\ (AGERI), Agricultural Research Center (ARC), Giza, 12619-Egypt.
}

Accepted February 26, 2013

\begin{abstract}
Trehalose is a non-reducing disaccharide which consists of two glucose units that functions as a compatible solute to stabilize the membrane structures under heat and desiccation stress. Trehalose-6phosphate synthase (TPS) and trehalose-6- phosphate phosphatase (TPP) are the key enzymes for trehalose biosynthesize in the plant kingdom. On the basis of bioinformatics prediction, fragment containing an open reading frame of 945 bp was cloned from durum wheat. Sequence comparison and analysis of conserved domains revealed the presence of a TPP domain. Full length of the gene was isolated using gene race technology. Semi-quantitative RT-PCR and real time quantitative PCR indicated that the expression of this gene is up-regulated in response to drought stress. The biochemical assay of the trehalase activity showed that the enzyme's activity decreased under the dehydration stress. The obtained phylogenic tree showed that the isolated TPP protein forms a distinct clad close to the Oryza sativa trehalose-6- phosphate phosphatase. In silico and comparative mapping indicated that the isolated TPP gene is localized on rice chromosome 8 , durum wheat chromosome 20, bread wheat chromosome 3B, oat linkage group E, sorghum chromosome 4 and barley $5 \mathrm{H}$.
\end{abstract}

Key words: Abiotic stress tolerance, trehalose-6- phosphate phosphatase (TPP), durum wheat, trehalose, real time PCR, cloning, full length gene, drought stress.

\section{INTRODUCTION}

The global food situation is currently being redefined by many driving forces like globalization, urbanization, energy prices, and climate change. According to the report of the food and agriculture organization of the United Nations (FAO) 2010, the number of undernourished

*Corresponding authors. E-mail: aymanalidiab@gmail.com. people around the world in 2010 has declined but remains abnormal and unacceptable. The renewed global attention is being given to the role of agriculture and food in development policy. One of the required actions that is suggested by the Egyptian Cabinet, Information and Decision Support Center (IDSC) to solve the food problem in Egypt was to focus on the agricultural research to enhance the capability of crop plants to withstand different abiotic stresses, such as salt, drought, 
cold and Heat shock which will lead to higher yields by either increasing the crop set and/or by extending crop cultivation in the areas previously denied due to abiotic stresses.

Understanding the gene networks that represent the biological system of plants under abiotic stress and their defense mechanism makes it necessary to characterize the candidate genes that are responsible for the physiological response to the stress. Trehalose is an important building block to build up sugars that create cellular signaling and communication. It is included in the building of a number of cell wall glycolipids. Trehalose is a disaccharide sugar widely distributed in bacteria, fungi, insects, plants and invertebrate animals. In microbes and yeast, trehalose is produced from glucose where trehalose-6-phosphate synthase (TPS) and trehalose-6phosphate phosphatase (TPP) function together as a large complex to synthesize trehalose. Moreover, TPS and TPP serve as sugar storage, metabolic regulator and protect living organisms against abiotic stress (Wiemken, 1990; Strom and Kaasen, 1993). Before 1997, it was thought that trehalose is present only in a few desiccation-tolerant plants. However, its role in plants was not yet fully elucidated. Under osmotic stress, trehalose was shown to accumulate at high levels in resurrection plants such as Selaginalla lepidophylla (Wingler, 2001) and as a sugar reserve or stress protectant in Arabidopsis thaliana (Goddijn and Smeekens, 1998; Vogel et al., 2002; Schluepmann et al., 2003). Interestingly, TPP and TPS genes are broadly found in the genomes of higher plants and form large gene families (Leyman et al., 2001; Schluepmann et al., 2004). Mellor (1992) considered trehalose as a symbiotic determinant between higher plants and microorganisms. However, there is no direct evidence supporting this hypothesis so far. It was found that the precursor of trehalose, trehalose-6-photophate, (T-6-P) is the key regulator in the glycolytic pathway (Blazquez et al., 1998). It targets the initial step of glycolysis to reduce the entrance of glucose into glycolysis. The same role of trehalose in the sugar metabolism was invistigated (Vogel et al., 1998; Paul, 2001; Wingler, 2001; Eastmond and Graham, 2003). From the results of genetic and reverse genetic analysis, trehalose was found to have an essential role in carbohydrate metabolism and development of higher plants. In Arabidopsis, loss of AtTPS1 function is an embryo-lethal phenotype (Eastmond et al., 2002; Schluepmann et al., 2003; Gomez et al., 2006); and a mutation in the maize TPP gene caused abnormalities in the inflorescence architecture (Satoh-Nagasawa et al., 2006). Trehalose content increased in rice as a result of the over expression of fused bacterial TPS and TPP proteins (named TPSP). The bi-functional TPSP protein enhanced the rice tolerance to abiotic stresses (Garg et al., 2002; Jang et al., 2003). Over expression of TPSP had a direct effect on the photosystem II damage under abiotic stress
(Garg et al., 2002; Jang et al., 2003). El-Bashiti et al. (2005) reported the possible role of trehalose as osmoprotectant compound in wheat species under salt and drought stress conditions. The accumulation of trehalose in wheat under abiotic stresses was found to be tissue and species specific.

Martı'nez-Barajas and his colleagues (2011) analyzed T6P content and SnRK1 activities in wheat (Triticum aestivum) grain. The data shows a correlation between $T 6 P$ and sucrose overall that belies a clear effect of developmental stage and tissue type on T6P content, consistent with tissue-specific regulation of SnRK1 by $T 6 P$ in wheat grain. Homologs of SNF1-related protein kinase1 (SnRK1) marker genes designated in Arabidopsis (Baena-González et al., 2007) was used to prove that regulation of SnRK1 by T6P could operate in vivo, using Wheat Estimated Transcript Server (WhETS; Mitchell et al., 2007).

In long term, the overexpression of trehalose biosynthetic genes in wheat may seem to be promising for improvement of abiotic stress tolerant transgenic wheat.

This work aimed at the isolation, cloning and characterization of functional trehalose-6-phospate phosphatase (TPP) gene from durum wheat under dehydration stress to investigate the trehalose 6 phosphatase (TPP) gene ability for drought tolerant in Durum wheat in order to examine the magnitude of the TPP gene response to drought stress.

\section{MATERIALS AND METHODS}

Plant materials, growth conditions and stress treatments

Durum wheat plants, (variety Sohag 3 ) presumably holding genes of resistance to drought were subjected to dehydration stress. Seeds of durum wheat (Triticum turgidum. L. var. durum wheat) were sterilized in $10 \%$ sodium hypochloride for $30 \mathrm{~min}$ and then rinsed with $\mathrm{ddh}_{2} \mathrm{O}$ for 1 min. Seeds were planted in soil composed of sand and clay (1:1) for three weeks and watered daily under

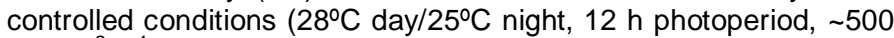
$\mathrm{mol} \mathrm{m} \mathrm{m}^{-2} \mathrm{~s}^{-1}$ photon flux density and $83 \%$ relative humidity). Drought treatment was applied as described by Ozturk et al. (2002) where, seedlings were removed from soil, washed carefully and placed on paper towels under the same growing conditions. Leaves were harvested after 2, 4, and $6 \mathrm{~h}$ of drought treatment, frozen in liquid nitrogen and stored at $-80^{\circ} \mathrm{C}$. Control seedlings were planted and grown concurrently in the same conditions without any drought regime (well-watered) then leaves were harvested at the same time and frozen in liquid nitrogen and stored at $-80^{\circ} \mathrm{C}$. For the estimation of water loss, leaves were weighted at the same time intervals as that used in the dehydration experiments (zero, 2, 4 and $6 \mathrm{~h}$ ). The ratio of the leaves weight in comparison to the control was used as indication of water loss.

\section{Total RNA isolation}

Total RNA was extracted according to Chomczynski (1993) where, $100 \mathrm{mg}$ of the control and drought treated leaves $(0,2,4$ and $6 \mathrm{~h})$ were ground in liquid nitrogen. $1 \mathrm{ml}$ of TriPure reagent (Cat. No. 1 667165 , Roche) was added to the fine leave powder and shacked gently. The mixture was left for $5 \mathrm{~min}$ at room temperature before 
adding $0.2 \mathrm{ml}$ of chloroform. The mixture was left at room temperature for $10 \mathrm{~min}$ then centrifuged for $15 \mathrm{~min}$ at $4^{\circ} \mathrm{C}$. Half $\mathrm{ml}$ isopropanol was added to the aqueous phase and incubated at room temperature for $10 \mathrm{~min}$. The samples were centrifuged at $12,000 \times g$ for $10 \mathrm{~min}$ at $4^{\circ} \mathrm{C}$. The RNA pellets were re-suspended in $75 \%$ ethanol then centrifuged at $7500 \times g$ for 5 min at $4^{\circ} \mathrm{C}$. The RNA pellets were dried and re-suspended in diethylpyrocarbonate (DEPC)-treated RNase-free water and stored at $-80^{\circ} \mathrm{C}$.

\section{Reverse transcription PCR (RT-PCR)-based cDNA cloning}

A pair of primers, (5'-ATGGATTTGAGCAATAGCTC-3' and 5'ACACTGAGTGCTTCTTCCAT-3') were synthesized and used to perform RT-PCR amplification using ImProm-IITM reverse transcription system (Cat. No. A3800, Promega). According to Liang and Pardee (1995), a cDNA of the TPP gene was generated using a RT-PCR based approach. The PCR cycle condition consists of three segments. The first one was a pre-denaturation for $4 \mathrm{~min}$ at $94^{\circ} \mathrm{C}$. The second variable segment was consists of 40 cycles each one was $1 \mathrm{~min}$ at $94^{\circ} \mathrm{C}, 1.5 \mathrm{~min}$ at $55^{\circ} \mathrm{C}$ and $2 \mathrm{~min}$ at $72^{\circ} \mathrm{C}$; the last segment was an extension for $10 \mathrm{~min}$ at $72^{\circ} \mathrm{C}$. The amplified cDNA fragment was purified and cloned for sequencing.

\section{Cloning of PCR product}

The PCR products were cloned in pGEM-T Easy plasmid (Promega, USA) and transferred into Escherichia coli DH5a. The white colonies were picked and screened for the presence of the cloned gene of interest through digestion with EcoRI (Sambrook et al., 1989). The pGEM®-T plasmid having TPP cDNA was selected by PCR using T7 and SP6 primers that amplify the $945 \mathrm{bp}$ fragment having the TPP gene. In this reaction, 1.25 units Taq DNA polymerase, $20 \mathrm{pmol}$ primers and $200 \mathrm{mM}$ dNTPS were added to $15 \mathrm{ng}$ of plasmid in a buffer containing $10 \mathrm{mM} \mathrm{KCl}, 10 \mathrm{mM}$ (NH4)2SO4, $20 \mathrm{mM}$ Tris $-\mathrm{HCl}-\mathrm{pH} 9$ and $0.1 \%$ Triton® X-100. The PCR cycle condition consists of three segments. The first was a pre-denaturation for $4 \mathrm{~min}$ at $94^{\circ} \mathrm{C}$. The second variable segment was of 40 cycles each one was 1 minutes at $94^{\circ} \mathrm{C}, 1 \mathrm{~min}$ at $55^{\circ} \mathrm{C}$ and 2 minutes at $72^{\circ} \mathrm{C}$; the last segment was an extension for 7 minutes at $72^{\circ} \mathrm{C}$.

\section{DNA sequencing and Bioinformatics analysis}

The TPP clone was sequenced according to Sanger et al. (1977) using a Big Dye Terminator Cycle sequencing FS Ready Reaction Kit (Applied Biosystems, Foster City, CA) and an ABI PRISM 310 DNA sequencer (Applied Biosystems). A homology search was performed using BLASTX against the NCBI protein database (http://www.ncbi.nlm.nih.gov). Sequences of the trehalose phosphate phosphatase genes that showed similarity to the TPP gene were obtained from the NCBI non-redundant and dbEST data sets using BLASTX or BLASTP ver. 2.0.10 (Altschul et al., 1997). The full amino acid sequences of the proteins were aligned using CLUSTAL- X ver. 1.8 (Thompson, et al., 1997) and subjected to phylogenetic analysis. Phylogenic trees were constructed using the neighbor-joining (NJ) method (Saitou, and Nei, 1987) with parsimony and heuristic search criteria and 1000 bootstrap replications to assess branching confidence.

\section{Rapid amplification of cDNA PCR (RACE-PCR)}

Rapid amplification of cDNA PCR was done to obtain the full length of TPP gene. According to Frohmann (1994), preparation of cDNA and anchor primers was conducted using Roche kit cat No.
1734792 (Clontech Lab, Inc). PCR was performed by using SP2 primer from advantage CDNA PCR kit (Clontech) and the primer $5^{\prime}$ CCTCCAGCACTTCGTTTACGAG-3' designed according to the gene sequence. PCR products were migrated by electrophoresis on $2 \%(\mathrm{~W} / \mathrm{V})$ agarose gel. The glass-milk (BIO 101) was used to recover and purify the DNA fragment, which was then ligated to pGEM®-T easy vector and finally transferred into Escherichia coli DH5 $\alpha$ (invetrogen, cat.No.18265-017). the cloned full length gene was sequenced using $\mathrm{ABI}$ PRISM big dye terminator cycle sequencing ready reaction kit (PE Applied Biosystem, USA).

\section{Expression patterns using semi- quantitative RT-PCR}

Template cDNA was prepared using Super-Script II (Invitrogen) with $1 \mathrm{mg}$ total RNA. $1 \mu \mathrm{l}$ of cDNA reaction mixture was diluted with $9 \mu \mathrm{LEPC}$ treated water, then, $1 \mu \mathrm{l}$ of diluted mixture was used to perform Semi-quantitative RT-PCR reaction as follows: $1.0 \mu \mathrm{l}$ dNTPS $(10 \mathrm{mM}), 2.5 \mu \mathrm{l} \mathrm{MgCl} 2(25 \mathrm{mM}), 5.0 \mu \mathrm{l}$ 10X buffer, $5.0 \mu \mathrm{l}$ Forward primer $(10 \mathrm{pmol} / \mu \mathrm{l}), 5.0 \mu \mathrm{l}$ Reverse primer $(10 \mathrm{pmol} / \mu \mathrm{l})$, $1.0 \mu \mathrm{l}$ Template cDNA $(25 \mathrm{ng} / \mu \mathrm{l}), 0.5 \mu \mathrm{l} \mathrm{Taq}(5 \mathrm{U} / \mu \mathrm{l})$, up to $50 \mu \mathrm{ldd}$ $\mathrm{H}_{2} \mathrm{O}$. The amplification was carried out in Hybrid PCR Express system programmed with specific primers for TPP and 18S (as a control to normalize the amount of cDNA present in each sample) genes as follows: $5 \mathrm{~min}$ at $95^{\circ} \mathrm{C}$, followed by 35 cycles at $95^{\circ} \mathrm{C}$ for $45 \mathrm{~s}, 55^{\circ} \mathrm{C}$ for $60 \mathrm{~s}, 72^{\circ} \mathrm{C}$ for 2 minutes, $72^{\circ} \mathrm{C}$ for 5 minutes. For each sample, $10 \mu \mathrm{l}$ of the amplification reaction was sizefractionated on a $2 \%(\mathrm{w} / \mathrm{v})$ agarose gel and stained with ethidium bromide. Bands were detected on UV-transilluminator and photographed by a Gel Documentation system 2000 Bio-Rad to ensure that amplifications were in the linear range, for each template and primer pair. A Gene Ruler ${ }^{\mathrm{TM}} 1 \mathrm{~kb}$ DNA ladder was used as a standard.

\section{Real-time PCR data analysis}

Primers of TPP and 18S used for semi-quantitative RT-PCR were used in real time PCR analysis. The most commonly used method for relative quantification is the $2^{-\Delta \Delta \mathrm{Ct}}$ method. Derivation and examples of this method have been described by Livak and Schmittgen (2001). The relative difference in gene expression using the $2^{-\Delta \Delta c t}$ method was calculated as follows:

Relative fold change in gene expression $=2^{-\Delta \Delta \mathrm{Ct}}$,

Where, $\Delta \Delta \mathrm{C}_{\mathrm{t}}=\Delta \mathrm{C}_{\mathrm{t}}$ treated $-\Delta \mathrm{C}_{\mathrm{t}}$ untreated and $\Delta \mathrm{C}_{\mathrm{t}}=\left(\mathrm{C}_{\mathrm{t}}\right.$ target gene $-C_{t}$ reference gene).

\section{Trehalase enzyme assay}

Samples weights about $100 \mathrm{mg}$ from drought treated leaves at $0 \mathrm{hr}$ (control), 2, 4, $6 \mathrm{hrs,} \mathrm{were} \mathrm{ground} \mathrm{in} \mathrm{liquid} \mathrm{nitrogen.} \mathrm{The} \mathrm{powder}$ was suspended in ice-cold suspension solution containing $0.1 \mathrm{M}$ citrate $(\mathrm{Na}+), \mathrm{pH} 3.7,1 \mathrm{mM}$ PMSF, $2 \mathrm{mM}$ EDTA and insoluble polyvinylpyrrolidone $(10 \mathrm{mg} / \mathrm{g}$ dried weight)). $2 \mathrm{ml}$ of extraction buffer was added to each $1 \mathrm{~g}$ dry weight of sample. The homogenate was filtered through two layers of cheesecloth and centrifuged at $31,500 \mathrm{rpm}(48,000 \mathrm{~g})$ for $30 \mathrm{~min}$ at $4{ }^{\circ} \mathrm{C}$ in Sorval Combi Plus with T-880 type rotor. The supernatant was used for the enzyme assays. Adapted from Vandercammen et al. (1989). The protein concentration was determined according to Bradford (1976) using bovine serum albumin (BSA) as standard.

Trehalase enzyme activity was measured using glucose oxidaseperoxidase kit (Bicon) according to Müller et al. (1992). The reaction mixture was composed of $10 \mathrm{mM}$ trehalose, $50 \mathrm{mM}$ MES $\left(\mathrm{K}^{+}\right), \mathrm{pH}$ 6.3 and $0.2 \mathrm{mg}$ crude extract in a final volume of $1 \mathrm{ml}$. 
Table 1. Leaves' weight of durum wheat under dehydration shock treatment.

\begin{tabular}{cc}
\hline Time of dehydration shock $(\mathrm{h})$ & Loss in water content of leaves (\%) \\
\hline Control 0 & 0 \\
2 & 15.79 \\
4 & 26.36 \\
6 & 34.5 \\
\hline
\end{tabular}

The reaction was incubated at $37^{\circ} \mathrm{C}$ for $30 \mathrm{~min}$ and then started by the addition of trehalose to the reaction mixture, which was preincubated at $37^{\circ} \mathrm{C}$ for $10 \mathrm{~min} .100 \mu \mathrm{l}$ of samples were taken from the reaction mixture and immediately put in thermostat at $100^{\circ} \mathrm{C}$ for $3 \mathrm{~min}$ to stop the reaction. Precipitates were removed by centrifugation at $8700 \mathrm{rpm}$ for $10 \mathrm{~min}$. For the analysis, $10 \mu \mathrm{l}$ of the supernatant was mixed with $\mu \mathrm{l}$ of glucose oxidase - peroxidase kit solution, mixed by vortex and then the mixtures were incubated at $37^{\circ} \mathrm{C}$ for $15 \mathrm{~min}$. The absorbance of the samples was measured at $470 \mathrm{~nm}$ in Schimadzu UV-1201 spectrophotometer against blank solution. The increase in the absorbance against time was assumed to be equal to the amount of glucose formed. One unit of trehalase activity is defined as the amount of enzyme that catalyzes the hydrolysis of $1 \mathrm{mmole}$ of trehalose/ minutes at $37^{\circ} \mathrm{C}$ at $\mathrm{pH} 6.3$.

\section{In silico and comparative mapping of TPP}

For in silico mapping, the isolated sequence was compared to rice and oat sequences using BLAST (with an e-value threshold of 1e1000). The matches were used to identify markers from the genetic linkage map (http://www.tigr.org). The results obtained from this stage were used to construct a comparative map between durum and bread wheat, rice, sorghum, barley and oat to identify the tentative chromosomal location of the gene understudy using comparative mapping strategy (Diab et al., 2007; Abou Ali et al., 2009).

\section{RESULTS AND DISCUSSION}

\section{Physiological parameters and dehydration stress- specific transcript profiles}

As shown in Table 1, leaves' weight was gradually decreased with dehydration time compared with the control (zero time dehydration). This weight losses indicates the decline in the water content of experimented leaves by $15.79,26.36$ and $34.5 \%$ for $2,4,6 \mathrm{~h}$ dehydration respectively. These results are in agreement with Ozturk et al. (2002) who found that the water content of barley declined by $10 \%$ within the initial $4 \mathrm{~h}$, and then more rapidly by $30 \%(6 \mathrm{~h})$ and $36 \%$ at $10 \mathrm{~h}$ of stress. Xue et al. (2008) reported that the change in relative leaf water content (LWC) of different genotypes indicated their different susceptibility to water scarcity. The dehydration treatment provides reliable, fast and easy way to detect genes responsible to abiotic stress response in physiological term (Talame et al., 2006).

\section{Molecular cloning of TPP fragment}

The RT-PCR reaction produced by TPP1 gene fragment with a length of $\approx 1000 \mathrm{bp}$ is shown in Figure 1 . The amplified TPP cDNA fragment was ligated into the pGEM-T easy vector (3015 bp) and transformed in Escherichia coli competent cells. The cloned TPP1 fragment was screened using T7 and SP6 primerd. Positive colonies having the insert displayed a band about $\approx 1300 \mathrm{bp}$ (TPP fragment with a length of $\approx 1000$ bp linked to the region between Sp6 and T7 in native pGEM-T easy plasmid $\approx 300 \mathrm{bp}$ ) (Figure 2 ).

\section{Sequence analysis of trehalose-6-phosphate phosphatase (TPP) fragment}

The isolated fragment was sequenced using ABI PRISM. Figure 3 shows the sequence obtained for the TPP fragment. Sequencing of the isolated fragment revealed that the length of Trehalose-6-phosphate phosphatase (TPP) fragment was $945 \mathrm{bp}$. The obtained sequence was subjected to the BLASTx analysis which proves that the sequence has different degrees of similarity with other TPP genes. The TPP fragment showed similarity to the TPP genes from O. sativa, (EU559275.1) 88\%, A thaliana (AY093147.1) $66 \%$ and $Z$. mays (NM_001158750.1) 66\%.

Isolation, cloning and characterization of the fulllength TPP gene

first strand of cDNA was synthesized according to Frohmann (1994) from total RNA using a gene specific CDNA primer SP2, (5'GGACGAACCTCTAAAACCATTC3'). The terminal transferase was used to add a homopolymeric A-tail to the $3^{\prime}$ end of the cDNA. Since eukaryotic coding sequences and 5'untranslated RNA regions tend to be biased toward $G / C$ residues, the use of a poly $(A)$-tail decreases the likelihood of inappropriate truncation by the Oligo dT-anchor primer. Additionally, poly (A)-tail was used due to the weaker $A / T$ binding than $G / C$ binding, therefore longer stretches of $A$ residues were required before the Oligo dT-anchor primer will bind to an internal site and truncate the amplification product. As shown in Figure 4, the full length of TPP gene that was obtained by RACE PCR was $\approx 1500 \mathrm{bp}$. PCR product was ligated into PGEM-T Easy Vector and then transformed into $E$. coli. The recombinant plasmid was digested by EcoR1 res- 


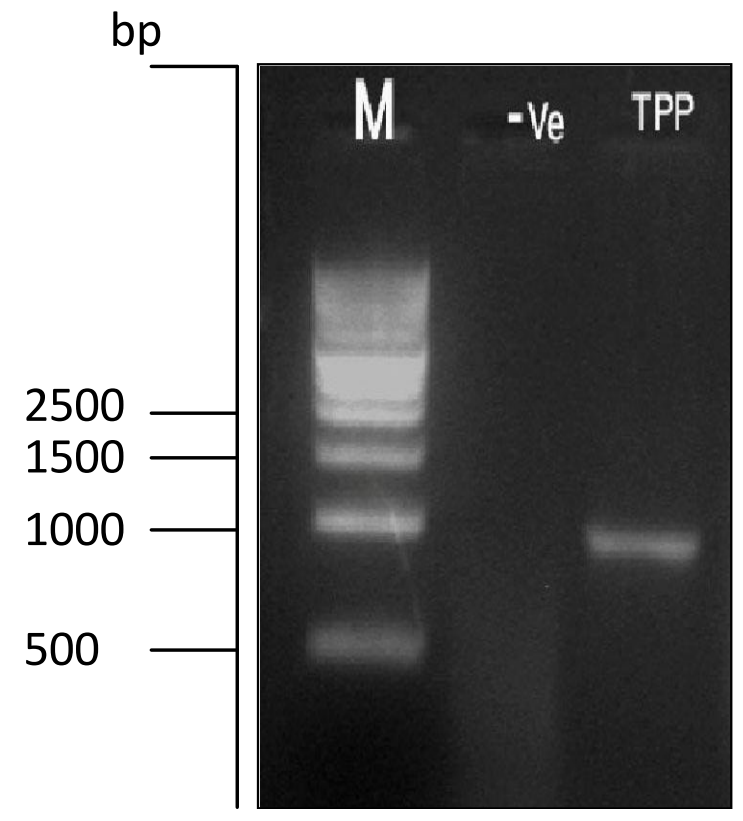

Figure 1. Agarose gel showing $1 \mathrm{~kb}$ marker (M), negative contr I (-ve), and TPP candidate band for TPP fragment.

triction enzyme to release the cloned gene. Two bands were obtained as a result of the digestion reaction of the recombinant plasmid. One was around $3000 \mathrm{bp}$ representing the vector (3015 bp) and the other was around $1500 \mathrm{bp}$ representing the insert (Figure 5).

The TPP gene(s) were isolated before in several studies. Shima et al. (2007) isolated OsTPP1 and OsTPP2 representing the two major trehalose-6-phosphate phosphatase genes expressed in rice, and they found that the rice genome contains nine TPP genes. The OsTPP2 gene encodes a $42.6 \mathrm{kDa}$ protein (382 amino acid residues). The same results were obtained by Pramanik and Imai (2005). They found nine putative TPP genes in the rice genome sequence. In Arabidopsis, 11 TPS and 10 TPP genes have been identified (Leyman et al., 2001; Eastmond and Graham, 2003). While Alexandrov et al. (2009) isolated 1883 bp trehalosephosphate phosphatase from $Z$. mays and $\mathrm{Ge}$ et al. (2008) isolated 1478 bp TPP1 gene from O. sativa.

The isolated full length gene was sequenced using $A B I$ PRISM (310 Genetic Analyzer); the sequence data is shown in Figure 6 . This sequence was utilized to run a homology search using blast tool provided by NCBI (http://blast.ncbi.nlm.nih.gov/Blast.cgi) (Altschul et al., 1997). The results of the homology research revealed that the isolated gene displayed different degrees of similarities to other TPP genes. The isolated durum wheat TPP showed similarity with the $O$. sativa, (AB120515.1) TPP by $93 \%$, A. thaliana, AY059840.1 by $68 \%$, Z. mays (NM_001158750.1) by $76 \%$.

According to the open reading frame of the isolated gene, the length of the protein that was expressed from

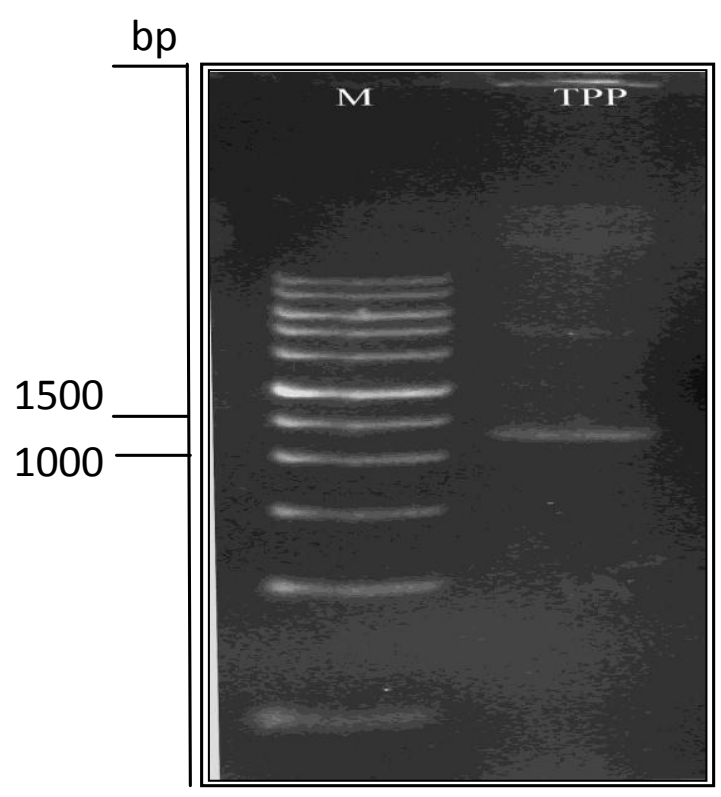

Figure 2. Agarose gel shows (M) $1 \mathrm{~kb}$ marker and amplified (TPP1) fragment using Sp6 and T7 primers.

the isolated gene was of 481 amino acid residues. The deduced amino acid sequence of the isolated TPP gene had a molecular weight of 53546.61 Daltons, and its isoelectric point was 10.37. The amino acid analysis results of TPP protein revealed that it contains 71 strongly basic amino acids, 40 strongly acidic amino acids, 172 hydrophobic amino acids, and 127 polar ami-no acids. Amino acids sequence of the TPP was analyzed using BLASTP. The results show that these sequences have high homologous sequence with different TPP amino acids sequences. The Durum wheat TPP had a similarity of $93 \%$ to O. sativa (AB120515.1), to Nicotiana tabacum (BAI99253.1) by $56 \%$, A. thaliana (NP_193990.1) by $56 \%, \quad Z$. mays (NP_001152222.1) by $53 \%$ and Arabidopsis lyratanigra (XP_002887719.1) by $42 \%$.

Alignment of the predicted amino acid sequence of TPP with proteins from other species identified several conserved regions are as shown in Figure 7. Pramanik and Imai (2005) reported that the alignment of the OsTPP1protien sequence with other TPP gene products from Saccharomyces cerevisae (ScTPS2), E. coli (EcOtsB) and Arabidopsis (AtTPPA and AtTPPB), revealed that TPP sequences are moderately conserved with exception in the $\mathrm{N}$-terminal region. The two distinct phosphatase boxes that are unique features of phosphatases are highly conserved (Vogel et al., 1998). Eastmond et al. (2002) investigated the TPP and TPS multigene family in plant sequences and suggested that trehalose biosynthesis is highly regulated by environmental changes in plants. Van Dijck et al. (2002) reported that, all TPS proteins in plants contain a conserved $\mathrm{N}$ terminal extension that not found in fungal or bacterial TPS proteins. 
TTTGTTAAACTAAAGGAGCTTAAGTAT AACGGAAACCATGACACAGCCACCGTATCA AATTTCT CAGAGGCATAA CAACATGACT AATAATAGTAAA CAAGCCAATATC AAT CGACCTA AACGCAATTTTCTAA CAGGGGACGG CAACATCATT CGACCCTAGC TAT GGATTGCC AACGCTGCAAAACAGTCGCCTGTCGGAAACTA CAGTCATCTC CTGTTT GTTC ATTATCGCAACGTTGCAGCGAGTG CTTGGAAACTGGTCTTCCATCTCACCAAG G AGTTCAGGAACGCT CTCCATCACT TCAGACGGGT CCCTGAGCGA GTAGAAGGCC TCGGATTCCT TCGGCGCCTG ACGAGACCAGT ATCCCGTATC CGCAGTTCCT CTCCC GAAGCACCTTGACTACG CGTCTTCGTC GGTGCGGTCG TCGCCGATGT AGATAGGGA T CACTTTCTCG GACTCGCTCA GCGCCAGCGA CTGAAGCAGG AATCGACGGC CTTC CCCTTG TCCCAGTCAAGAAGAGATCACTGGACG AACCTCTAAA ACCATTCGTC CGT TGGGAGATCAC TTTGAGACGG GGGAAGTCCT CCAGCACTTC GTTTGACGAGC CGT GCGACCA GCTCCCAGTCAAGAAGA CTTCTCGTCC ACGTTGCGGTAATGTACAGA CA CGCAGAAC TTGTTGTAGCCT CAACGCTTGC GCCTTCGATT CGGCTCGTGACTTCCA AGAG GACCTTGGAA ACCTCATCGA TCATAGGCAG AAAATCGCGA GCAGTTGGAA GAGGTTGGCT TCTTTGCCCT TTTCAGCATT GCGTTCATAA TGTGCTGAAG GATGGT TCATTA TGTCCATCGCC ATTGTAGACTACCA GCATAGCAGA GTTCCTTCAG ATTTA CGAAT TCAAGAACCTTATTCGGGGA CCTTCCATTG TCCGTGTCAA AAAGAAAAAA AGTAAAAAA

Figure 3. Nucleotide sequence of (TPP) fragment representing $945 \mathrm{bp}$.

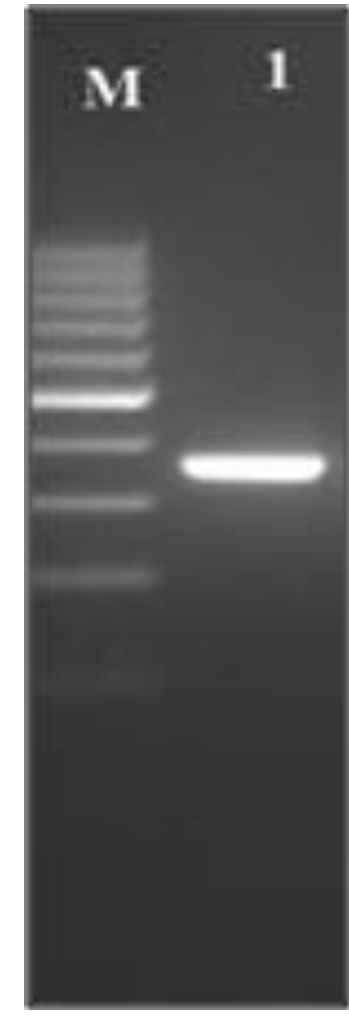

Figure 4. Agarose gel electrophoresis of genespecific fragment (TPP1) gene $\approx 1500 \mathrm{bp}$ isolated by RACE-PCR.

To determine the evolutionary relatedness of TPP protein to Trehalose 6 phosphate phosphatase proteins isolated from other species, the neighbor joining method

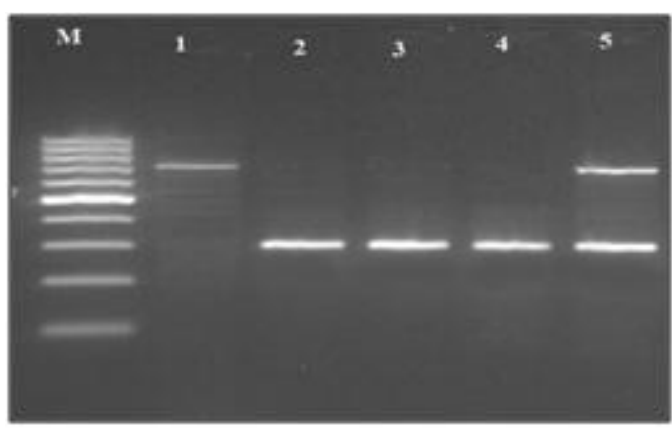

Figure 5. Agarose gel representing digestion of candidate colonies with EcoRI enzyme, $1 \mathrm{~kb}$ marker (M), pGEM-T vector (1), (TPP) gene $(2,3,4)$ and positive colony plasmid (5) DNA digestion.

(NJ) was used to generate a phylogenic tree based on amino acid sequence homology. The tree showed that TPP protein forms a distinct clad on phylogenetic trees derived from various TPP sequences (Figure 8). Bootstrap analysis placed the durum wheat (Triticum durum) sequence close to $O$. sativa with a high degree of confidence, demonstrating that the two species descent from common ancestor.

\section{Protein sequence analysis homology modeling}

The results of BLAST search against PDB program exhibited a high level of sequence similarity to the crystallized structure for modeling TPP protien (Figure 9). This protein structure is very important to study the mode of action of disaccharides, like trehalose that appear to be one of the most effective stabilizers for dried enzymes 


\begin{abstract}
(A)
ATGGATTTGA GCAATAGCTC ACCTGTCATC ACCGATCCGG TGTCGATCAG CCA GCAGCTGTTGCGCGCCC TGCCTTCAAA TCTGATGCAG ATTTCAGTCA TGCGCGG TGG CTACTCCAGCTCTCGCATGG ACGTTGGTGT CAGTAGGCTC ATAATCGAGG AAGACCTTGTCAATGGACTGCTTGATGCGA TGAAATCCTG CTCACCTCGC AGGA GGCTGA GTGTAGCAAT TGGCGAGGACAATTCATCTG AAGAAGATGACGCTGCTT AC AGCGCTTGGA TGGCAAAATG TCCTTCTGCATTGGCTTCCT TCAAGCGAAT TG AAGCGAGT GCACAAGGGA AGGAGATTGC TGTGTTTCTAGACTATGACG GCACA CTGTC GCGTATTGTG GATGATCCTG ACAAAGCAGT GATGTCTCCCGTGATGAGT G CTGCTGTGAG AGATGTTGCG AAGTACTTCC CCACTGCAAT TGTCAGCGGA A GGTCCCGCA ATAAGGTGTTTGAATTTGTTAAACTAAAGGAGCTTAAGTAT AACG GAAACCATGACACAGCCACCGTATCAATTTCT CAGAGGCATAA CAACATGACT A ATAATAGTAAA CAAGCCAATATC AATCGACCTA AACGCAATTTTCTAA CAGGG GACGG CAACATCATT CGACCCTAGC TATGGATTGCC AACGCTGCAAAACAGTC GCCTGTCGGAAACTA CAGTCATCTC CTGTTTGTTC ATTATCGCAACGTTGCAGCG AGTG CTTGGAAACTGGTCTTCCATCTCACCAAGG AGTTCAGGAACGCT CTCCAT CACT TCAGACGGGT CCCTGAGCGA GTAGAAGGCCTCGGATTCCT TCGGCGCCTG ACGAGACCAGT ATCCCGTATC CGCAGTTCCT CTCCCGAAGCACCTTGACTACG C GTCTTCGTC GGTGCGGTCG TCGCCGATGT AGATAGGGAT CACTTTCTCG GACTC GCTCA GCGCCAGCGA CTGAAGCAGG AATCGACGGC CTTCCCCTTG TCCCAGTC AAGAAGAGATCACTGGACG AACCTCTAAA ACCATTCGTC CGTTGGGAGATCAC TTTGAGACGG GGGAAGTCCT CCAGCACTTC GTTTGACGAGC CGTGCGACCA GC TCCCAGTCAAGAAGA CTTCTCGTCC ACGTTGCGGTAATGTACAGA CACGCAGAA C TTGTTGTAGCCT CAACGCTTGC GCCTTCGATT CGGCTCGTGACTTCCAAGAG G ACCTTGGAA ACCTCATCGA TCATAGGCAG AAAATCGCGA GCAGTTGGAA GAG GTTGGCT TCTTTGCCCT TTTCAGCATT GCGTTCATAA TGTGCTGAAG GATGGTT CATTA TGTCCATCGCC ATTGTAGACTACCA GCATAGCAGA GTTCCTTCAG ATTT ACGAAT TCAAGAACCTTATTCGGGGA CCTTCCATTG TCCGTGTCAA AAAGAAAA AA AGTAAAAAA
\end{abstract}

\title{
(B)
}

MDLSNSSPVITDPVSISQQLLRALPSNLMQISVMRGGYSSSRMDVGVSRLIIEEDLVNG LLDAMKSCSPRRRLSVAIGEDNSSEEDDAAYSAWMAKCPSALASFKRIEASAQGKEI AVFLDYDGTLSRIVDDPDKAVMSVMSAAVRDVAKYFPTAIVSGRSRNKVFEFVKLKE LKYNGNHDTATVSISQRHNNMTNNSKQANINRPKRNFLTGDGNIIRPLWIANAAKQS PVGNYSHLLFVHYRNVAASAWKLVFHLTKEFRNALHHFRRVPERVEGLGFLRRLTRP VSRIRSSSPEAPLRVFVGAVVADVDRDHFLGLAQRQRLKQESTAFPLSQSRRDHWTN LNHSSVGRSLDGGSPPALRLTSRATSSQSRRLLVHVAVMYRHAELVVASTLAPSIRLV TSKRTLETSSIIGRKSRAVGRGWLLCPFQHCVHNVLKDGSLCPSPLTTSIAEFLQIYEFK NLIRGPSIVRVKKKKSKK.

Figure 6. (A) Nucleotide sequence of (TPP1) gene representing 1458 bp as obtained from the ABI PRISM 310 DNA sequencer. (B) The amino acid sequence (481 aa).

and cell membranes in vitro and in vivo. However, the interaction of trehalose with biological membranes has been studied more than its interactions with other proteins.

Carpenter (1993) has reported that trehalose might interact with dry protein by hydrogen bonding to the polar amino acid residues in the protein. On the other hand, the interaction between trehalose and biological membranes indicates that trehalose can replace $\mathrm{H}_{2} \mathrm{O}$ molecules around the polar head groups of the phospholipid in the dry state (Gaber et al., 1986). This hypothesis has been studied by Potts (1994) where trehalose binds to dry phospholipid vesicles. During desiccation, the interaction of trehalose with the biological membrane decreases the melting temperature $(\mathrm{Tm})$ of the membrane to keep its liquid crystalline phase (Crowe et al., 1993). This molding could be used to predict the interaction between the trehalose and other protein candidates in the biological membranes for more understanding of the trehalose mode of action for protecting plants against abiotic stress conditions.

\section{Expression analysis}

The results obtained in this work indicate that the expression of the TPP gene was up-regulated under dehydration stress compared to control (Figure 10). The highest expression level of TPP gene under dehydration stress was at $4 \mathrm{~h}$. This up-regulation is important for the synthesis and accumulation of trehalose where, trehalose 


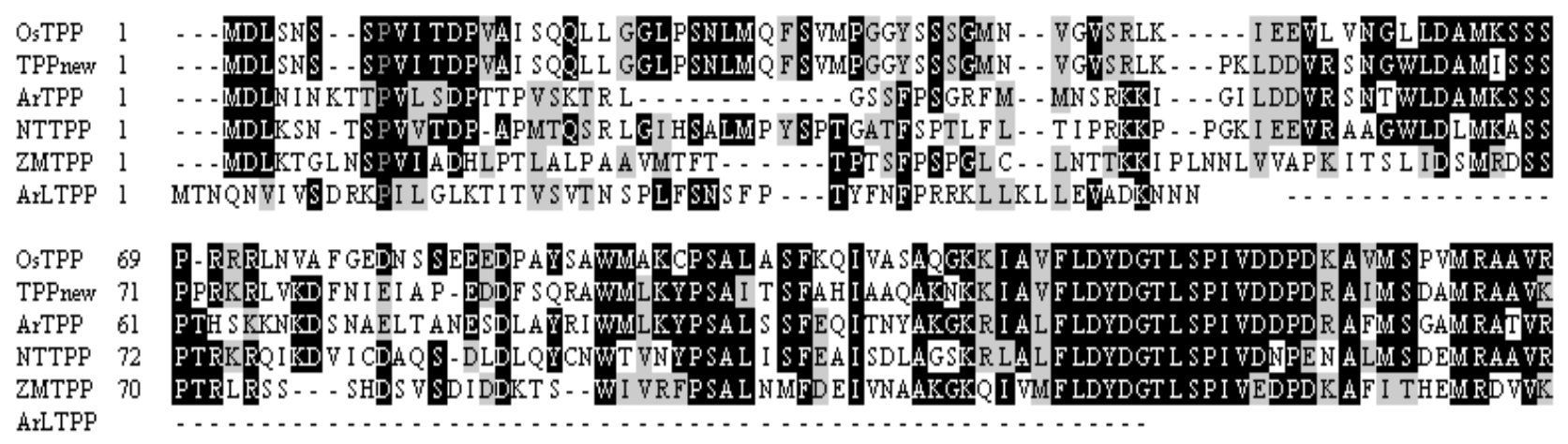

OSTPP 148 WVAKYFPTA I WSGRS RNKVFEF VKLK ELYYAGSH GMDIMAFSANHEHSA E - . . . . . . - KSKRANLFQ PAH DFLPMIDEV

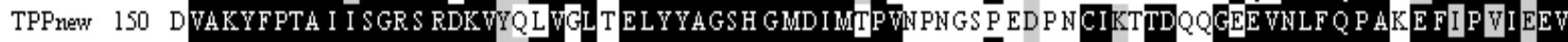
AYTPP 141 NVAKYFPTA I I SGR S RDKWD F VGL A ELYYAGSH GMDIMGPVR - S SVDDY SCIKFTDKO GKE VHLFQ P A S E FL PMIDEV NTTPP 151 HAA S LFPTA I I SGR S RDKVFD F WLL N ELYYAGS H GMD IMGPVRKTTDS G GV ECIRSTD VHGKE VNLF Q P A S FL PMITEV

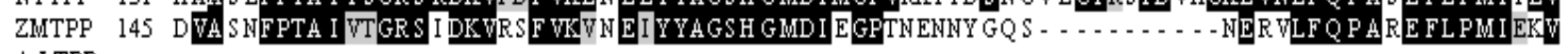
AYLTPP

OsTPP 219 TKS LLQVUS GIEGAT VENHKF CVS VH Y RN WAEKDWKLVARLWNEVLEA FPR LKVTWGGMVLEVRPVI E WNKGKA VEFLLE TPPnew 230 Y YNH L WE I TKC I I GAK V ENHKF CTS VH Y RN WD EKD WP LVA QRWHDHLK R Y P R L RI THGRK VLEVR P VL NWDK GKA V E FLLE AYTPP 219 FRS LWELTK D IT GAK V ENHKF C VS V H Y RN WDEKS SWS A I GE SWDELLKHY Y R L RLTHGRK VFEVR PVI DWNK GKA VE FLLE

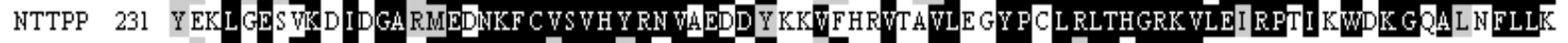
ZMTPP 214 I KI LEEKTKWI GAMVENHKF CIS VH FERWEK RWT ALAEVUKSVLI DY PE LKLTQGRK V

ArLTPP

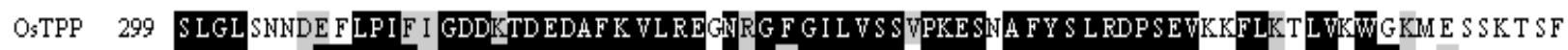

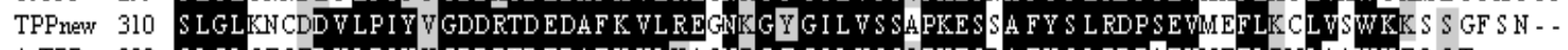

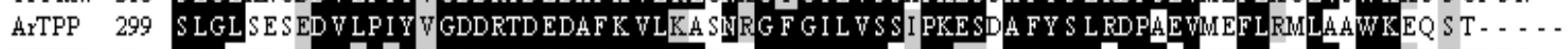
NTTPP 311 SLGY ED SEDVWPVY I GDDRTD EDAF K VLRERGQ G F GI L V SKVPKDTHA FY S LODPSOVWKELE RLVEWKRK T VGE E - -

ZMTPP

AYLTPP

Figure 7. Alignment of the predicted amino acid sequence of TPP and those from other plants including Arabidopsis lyrata (ArLTPP), Zea mays (ZmTPP), Arabidopsis thaliana (ArTPP), Nicotiana tabacum(NtTPP), Oryza sativa (OsTPP).

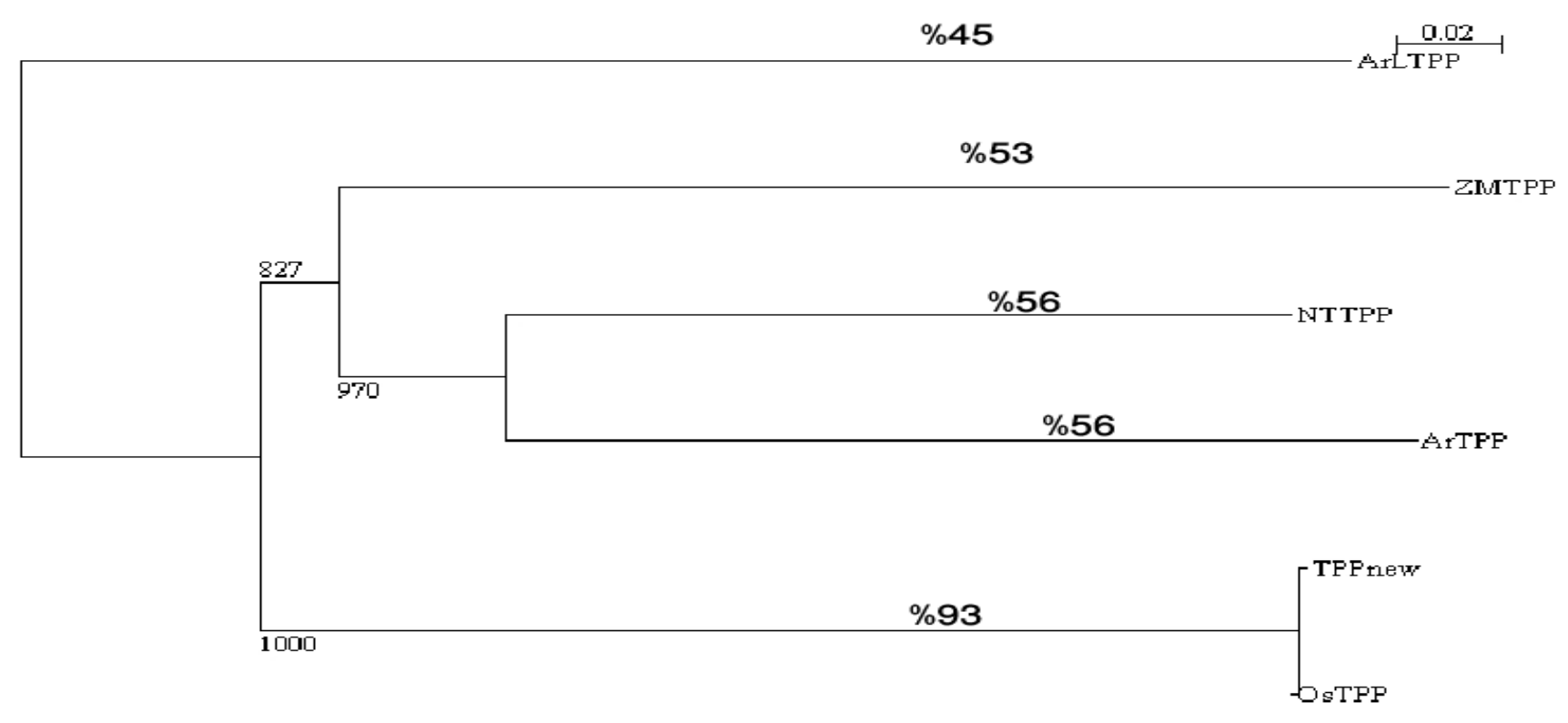

Figure 8. Phylogenetic tree based on sequences of TPP1 with other TPP's isolated from other plants. The phylogenetic tree was constructed by the neighbor-joining including Arabidopsis lyrata (ArLTPP), Zea mays (ZmTPP), Arabidopsis thaliana (ArTPP), Nicotiana tabacum (NtTPP), Oryza sativa (OsTPP). 


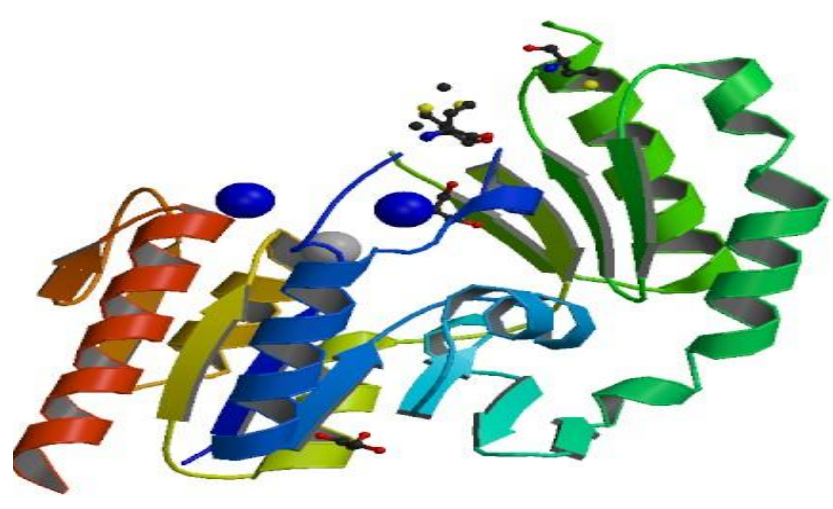

Figure 9. 3D Model of TPP protein structure.

is accumulated in large quantities under abiotic stresses (Elbein et al., 2003 and Wolf et al., 2003).

Reserve transcription combined with the polymerase chain reaction (RT-PCR) has proven to be a powerful method to quantify gene expression according to Murphy et al. (1990). Real-time PCR technology has been adapted to perform quantitative RT-PCR (Heid et al., 1996). The results of the real time PCR of the TPP gene showed that the expression level of TPP was slightly increased (up-regulated) after $4 \mathrm{~h}$ of dehydration treatment in leaves of Durum wheat compared with the control $(0 \mathrm{~h})$ and the relative fold change calculated by $\triangle \triangle C T$ method, respectively which in agreement with the semi-quantitative PCR results (Figures 11 and 12). The plant's response to dehydration is accompanied by the activation of a group of genes, which are responsible for regulatory proteins that further regulate the transduction of the stress signal and modulate gene expression (Shinozaki and Yamaguchi, 2006).

Higo et al. (2006) studied the expression of trehalose gene synthesis ( $m t s$ and $m t h$, encoding maltooligosyl trehalose synthase and hydrolase) and trehalose hydrolysis (treH) in Anabaena sp. The genes (mts and mth) were up-regulated markedly upon dehydration. Gene disruption of mth resulted in a decrease in the trehalose level and in tolerance during dehydration stress. In contrast, gene disruption of $\mathrm{treH}$ resulted in an increase in both the amount of trehalose and tolerance. Trehalose did not stabilize proteins and membranes directly during dehydration; the expression of the two genes, one of which encodes a cofactor of a chaperone DnaK, correlated with trehalose content, a chaperone system induced by trehalose is important for the dehydration tolerance of Anabaena sp.

Cumino et al. (2002) found that many other genes, including $s p s A$, encoding sucrose-6-phosphate synthase were up-regulated constantly during dehydration stress. Many genes related to hotosynthesis and ribosomal protein was down-regulated in the early dehydration phase, whereas genes for nitrogen fixation and photosynthesis I was down-regulated in the late dehydration phase.

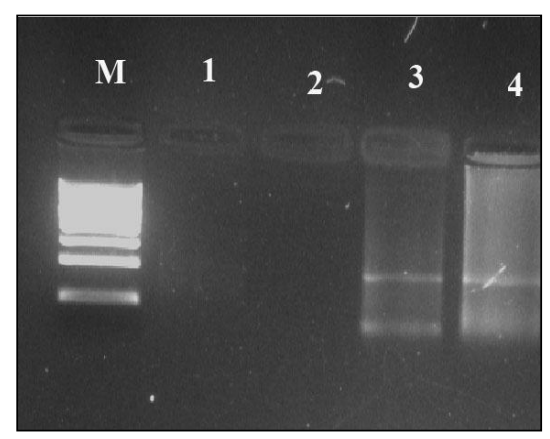

Figure 10. Agarose gel represents the TPP expression patterns of leaves under dehydration stress treatment after 0 (1), 2

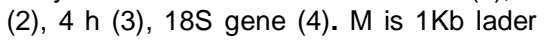
DNA marker.

\section{Determination of trehalase activity under dehydration stress}

As shown in Table 2, the activity of trehalase enzyme under dehydration stress was decreased from 1.004 to 0.781 after $2 \mathrm{~h}$ and to 0.427 after $4 \mathrm{~h}$. The activity was then elevated after $6 \mathrm{~h}$ of dehydration treatment compared to the control (Figure 13). The elevation of trehalse activity after $6 \mathrm{~h}$ might be due to internal regulation mechanism in the system biology of the plant to prevent the uncontrolled increase of the trehalose which is important to prevent detrimental effects of trehalose accumulation on the regulation of carbon metabolism (Brodmann, 2002).

These results are in agreement with Brodmann (2002) who showed that trehalase activity normally keeps cellular trehalose concentrations low in order to prevent detrimental effects of trehalose accumulation on the regulation of carbon metabolism. The role of trehalase may be of particular importance in interactions of plants with trehalose-producing microorganisms. In support of this hypothesis, expression of the Arabidopsis trehalase gene and trehalose activity were found to be strongly induced by infection of Arabidopsis plants with the trehalose-producing pathogen Plasmodiophora brassicae. Penna (2003) found that trehalose was thought to protect biomolecules from environmental stress, as suggested by its reversible water-absorption capacity to protect biological molecules from desiccationinduced damage. The low levels of trehalose in transgenic plants can be explained by specific trehalase activity, which degrades trehalose; hence, it might be possible to increase trehalose accumulation by down regulating trehalase activity. El-Bashiti et al. (2005) found that trehalase activity in different wheat cultivar was increased under control conditions in both root and shoot of Bolal cultivar compared with salt and drought stress treatments. However, under drought conditions, there was no significant change in trehalase activity of shoot tissues. Trehalase is ubiquitous in higher plants and 


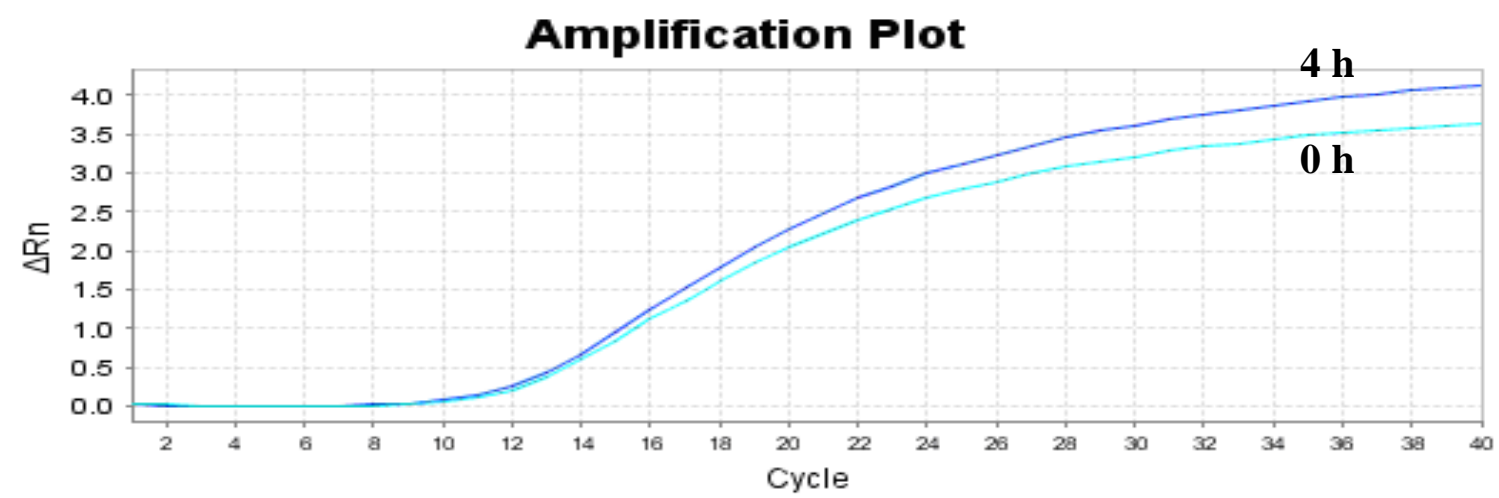

Figure 11. Variation of fluorescence amplification plot of TPP1 gene for the dehydration shock treatments $(0$ and $4 \mathrm{~h}$ )

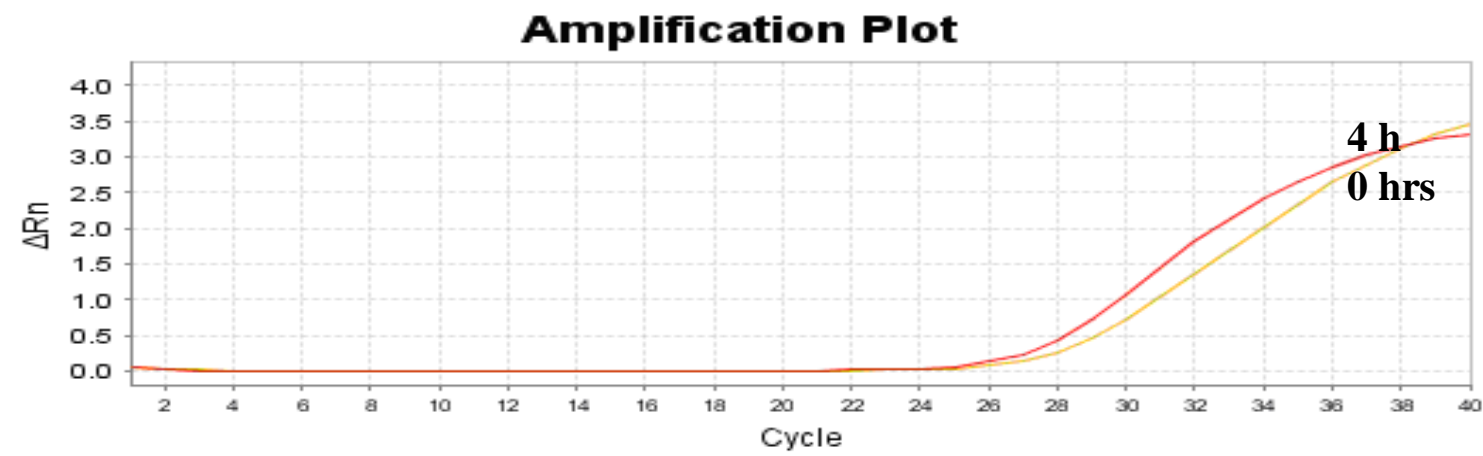

Figure 12. Normalization of fluorescence amplification plot of $18 \mathrm{~S}$ gene (reference gene) for the three dehydration shock treatments $(0,4 \mathrm{~h})$.

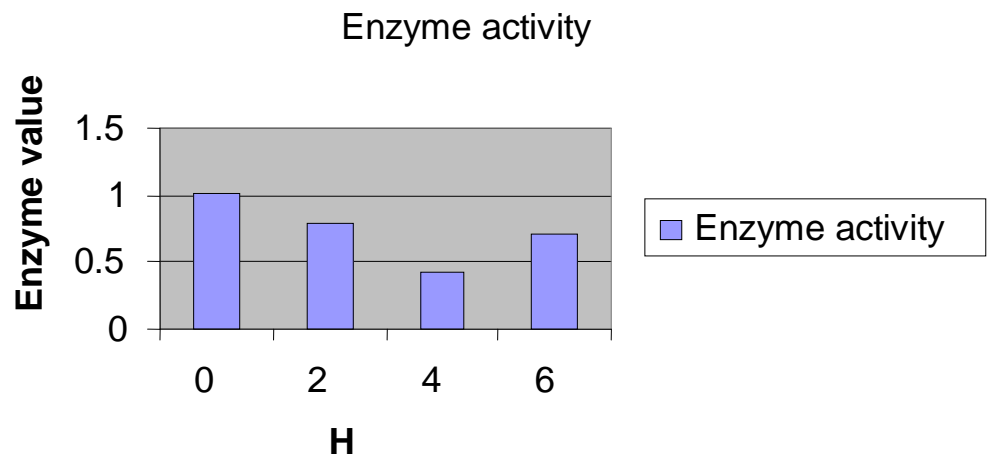

Figure 13.The trehalase activity after dehydration shock treatments.

Table 2. Trehalase activity under dehydration shock treatments.

\begin{tabular}{cc}
\hline Hour & Enzyme activity \\
\hline 0 & 1.004 \\
2 & 0.7813 \\
4 & 0.4273 \\
6 & 0.7170 \\
\hline
\end{tabular}




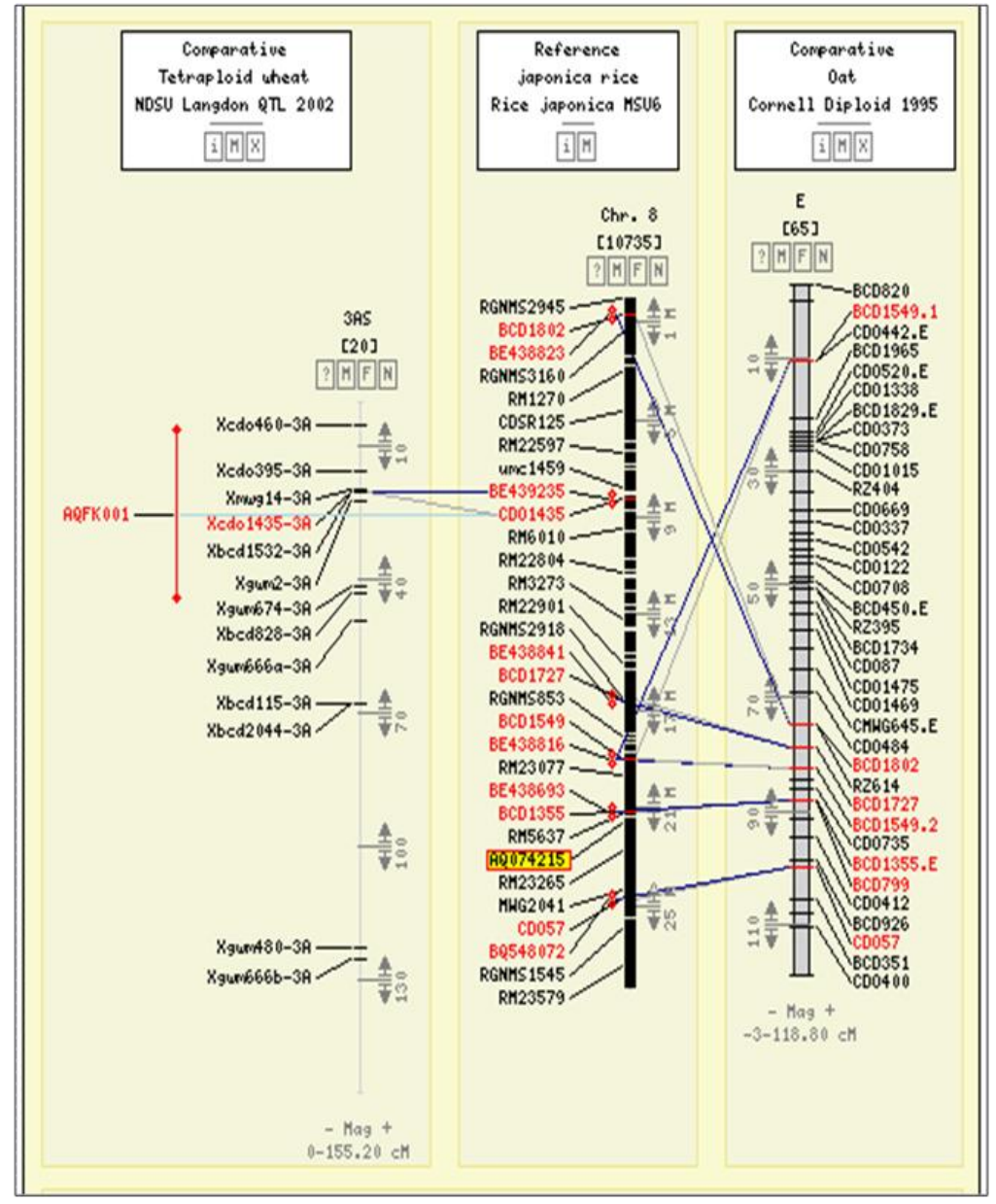

Figure 14. Comparative map showing the locus AQ074215 on Rice chromosome 8 that is closely linked to other locus on Oat and Tetraploid wheat.

single-copy trehalase genes have been identified and functionally characterized from soybean (Glycine max) and Arabidopsis (Aeschbacher et al., 1999; Müller et al., 2001). It is likely that trehalase is the sole route of trehalose breakdown in plants (Müller et al., 2001). Katoh et al. (2004) concluded that although TPS catalyses the transfer of glucose from UDP-glucose to glucose 6phosphate to produce trehalose 6-phosphate and UDP, and TPP catalyses the dephosphorylation of trehalose 6phosphate to trehalose. The low level of accumulation of trehalose may be attributed to the unique gene structure for trehalose metabolism. They investigated the expression of genes for trehalose synthesis, mth (maltooligosyl trehalose hydrolase) and $m t s$ (maltooligosyl trehalose synthase), as well as that for trehalose degradation, tre $\mathrm{H}$ (trehalase), exhibited marked increase upon dehydration. So trehalose did not accumulate so much.

\section{In silico and comparative mapping}

Comparative maps can be used to study genome evolu- tion; how the genome has been rearranged through time, and to make inferences about gene organization (Liang et al., 2008). In-silico mapping indicated the matching of the TPP gene sequence with the sequence of rice TPP on chromosome 8 linked to the locus (AQ074215).

Comparative mapping showed that the rice AQ074215 locus on chromosome 8 was also mapped on barley chromosome $5 \mathrm{H}$. The marker (Iwgsc) on bread wheat chromosome 3B was found to be closely liked to the rice locus (AQ074215) on chromosome 8. The results obtained from the comparative mapping showed that the isolated TPP gene is localized on rice chromosome 8, durum wheat chromosome 20 , bread wheat chromosome 3B, oat linkage group $E$, sorghum chromosome 4 and barley $5 \mathrm{H}$ (Figures 14 to 16). This work utilizes a comparative analysis of durum and bread wheat, barley, oat, sorghum and rice based on linkage maps and consensus markers across the genome with the goal of linking the complex wheat genome to simpler diploid species such as barley and rice that serve as references. However, more detailed comparisons are needed to veri- 


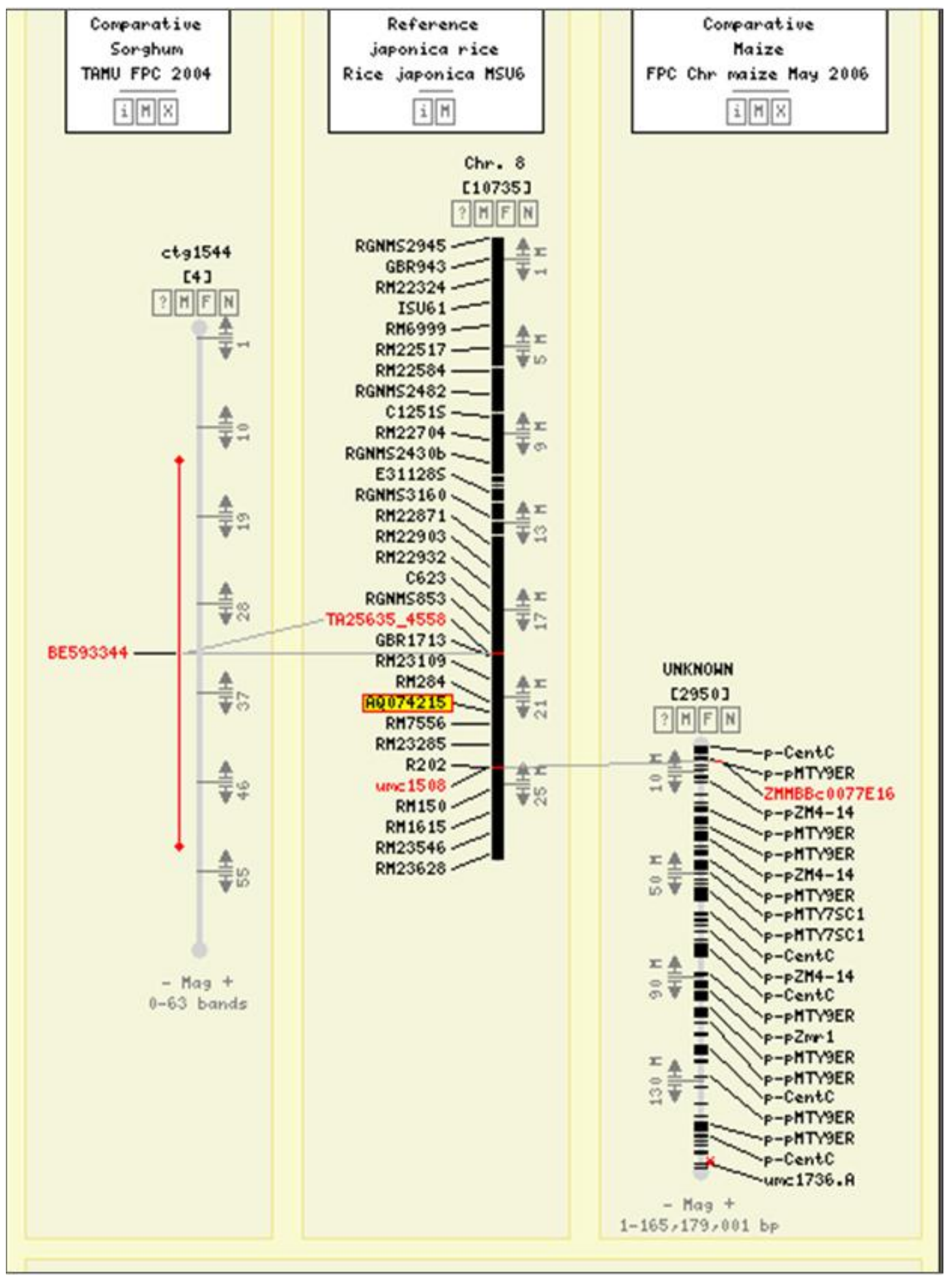

Figure 15. Comparative map showing the locus AQ074215 on rice chromosome 8 and maize and sorghum.

fy conserved regions associated the TPP gene.

In this study, the TPP gene was isolated, characterized and cloned to be used in the strategic improvement of crops for abiotic stress tolerance through genetic transformation and the in silico comparative mapping of this gene would open the gate for the use of the TPP gene for marker assisted selection in breeding programs for abiotic stress tolerant crops. 


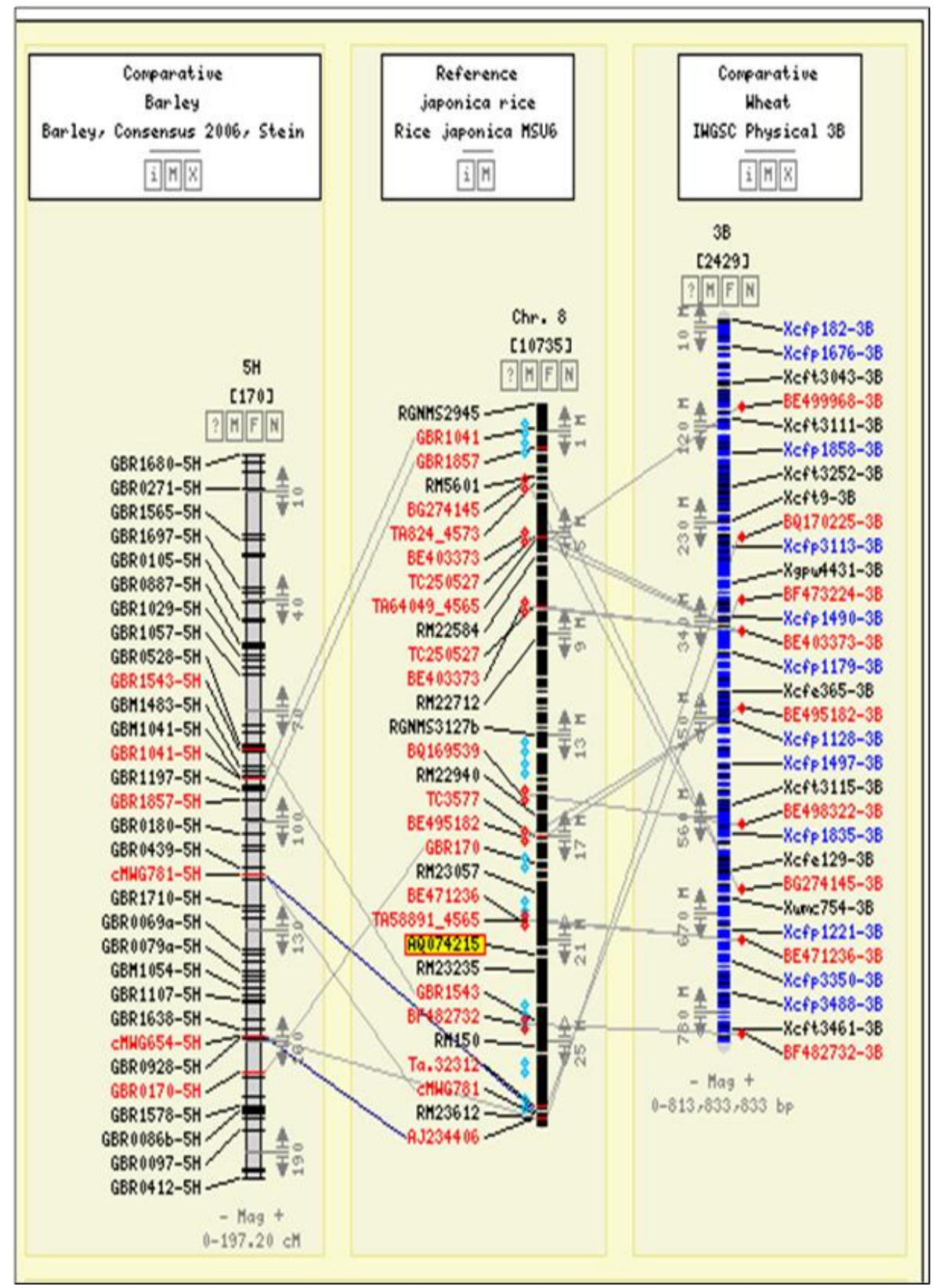

Figure 16. Comparative map showing the locus AQ074215 on Rice chromosome 8 . and its linkage to barley and bread wheat.

\section{REFERENCES}

Abou Ali R, El-Hefnawy M, Nada A (2009). Isolation and characterization of Cab8 gene from wild Vicia cinera species. Egyptian J. Genet. Cytol. 38:335-346.

Aeschbacher RA, Müller J, Boller T, Wiemken A (1999). Purification of the trehalase GMTRE 1 from soybean nodules and cloning of its cDNA: GMTRE 1 is expressed at a low level in multiple tissues. Plant Physiol. 119:489-496.

Alexandrov NN, Brover VV, Freidin S, Troukhan ME, Tatarinova TV, Zhang $\mathrm{H}$, Swaller TJ, Lu YP, Bouck J, Flavell RB, Feldman KA (2009). Insights into corn genes derived from large-scale cDNA sequencing. Plant Mol. Biol. 69:179-194.

Altschul SF, Madden TL, Schäffer AA, Zhang J, Zhang Z, Miller W,
Lipman DL, (1997). Gapped BLAST and PSI-BLAST: A new generation of protein database search programs. Nucleic Acids Res. 25:3389-3402.

Baena-González E, Rolland F, Thevelein JM, Sheen J (2007). A central integrator of transcription networks in plant stress and energy signalling. Nature 448:938-942.

Blazquez MA, Santos E, Flores CL, Martinez-Zapater JM, Salinas J, Gancedo C (1998). Isolation and molecular characterization of the Arabidopsis TPS1 gene, encoding trehalose-6-phosphate synthase. Plant J. 13:685-689.

Bradford MM (1976). A rapid and sensitive method for the quantification of microgram quantities of protein utilizing the principle of protein-dye binding, Anal. Biochem. 72:248-254.

Brodmann A, Schuller A, Müller J, Aeschbacher RA, Wiemken A, Boller 
T, Wingler A (2002). Introduction of trehalose in Arabidopsis plants infected with the trehalose-producing pathogen Plasmodiphora brassicca, Mol. Plant Microb. Interact. 15:693-700.

Carpenter JF (1993). Stabilization of proteins during freezing and dehydration: application of lessons from nature. Cryobiology 30:220221.

Chomczynski $P$ (1993). A reagent for the single-step simultaneous isolation of RNA, DNA and proteins from cell and tissue samples. BioTechniques 15:532-537.

Crowe JH, Crowe LM, Leslie SB, Fisk E (1993). Mechanisms of stabilization of dry biomolecules in anhydrobiotic organisms. In: Close TJ, Bray EA (eds.), Plant Responses to Cellular Dehydration During Environmental Stress. Am. Soc. Plant Physiol. Riverside, CA. pp. 1120.

Cumino A, Curatti L, Giarrocco L, Salerno GL (2002). Sucrose metabolism: Anabaena sucrose-phosphate synthase and sucrosephosphate phosphatase define minimal functional domains shuffled during evolution. FEBS Lett. 517:19-23.

Diab AA, Ageez A, Abdelgawad BA, Salem TZ (2007). Cloning, sequence analysis and in silico mapping of a drought-inducible gene coding for s-adenosylmethionine decarboxylase from durum wheat. World App. Sci. J. 2(4):333-340.

Eastmond PJ, Graham IA (2003). Trehalose metabolism: a regulatory role for trehalose-6-phosphate? Curr. Opin. Plant Biol. 6:231-235.

Eastmond PJ, Van Dijken AJ, Spielman M, Kerr A, Tissier AF, Dickinson HG, Jones JD, Smeekens SC, Graham IA (2002). Trehalose- 6-phosphate synthase 1, which catalyses the first step in trehalose synthesis, is essential for Arabidopsis embryo maturation. Plant J. 29:225-235.

El-Bashiti T, Hamamcı H, Oktem HA, Yucel M (2005). Biochemical analysis of trehalose and its metabolizing enzymes in wheat under abiotic stress conditions. Plant Sci. 169:47-54.

Elbein ADYT, PanYT, Pastuszak I, Carroll D (2003). New insights on trehalose: a multifunctional molecule. Glycobiol. 13:17R-27R.

FAO, WFP (2010).. The State of Food Insecurity in the World, Addressing food insecurity in protracted crises. Food and Agriculture Organization of the United Nations Rome.

Frohman MA (1994). On beyond classic RACE (rapid amplification of cDNA ends). Meth. Appl. 4:S40-58.

Gaber BP, Chandrasekhar I, Pattabiraman N (1986). The interaction of trehalose with the phospholipid bilayer:a molecular modeling study. In: Leopold AC (ed.), Membranes, metabolism and dry organisms. pp. 231-241.

Garg AK, Kim JK, Owens TG, Ranwala AP, Choi YD, Kochian LV, Wu RJ (2002). Trehalose accumulation in rice plants confers high tolerance levels to different abiotic stresses. Proc. Natl. Acad. Sci. USA 99:15898-15903.

Ge LF, Chao DY, Shi M, Zhu MZ, Gao JP, Lin HX (2008). Overexpression of the trehalose-6-phosphate phosphatase gene OsTPP1 confers stress tolerance in rice and results in the activation of stress responsive genes. Planta 228:191-201.

Goddijn O, Smeekens S (1998). Sensing trehalose biosynthesis in plants. Plant J. 14:143 146.

Gomez LD, Baud S, Gilday A, Li Y, Graham IA (2006). Delayed embryo development in the Arabidopsis Trehalose- 6-phosphate synthesis 1 mutant is associated with altered cell wall structure, decreased cell division and starch accumulation. Plant J. 46:69-84.

Heid CA, Stevens J, Livak KJ, Williams PM (1996). Real time quantitative PCR. Genome Res. 6(10):986-994.

Higo A, Katoh H, Ohmori K, Ikeuchi M, Ohmori M (2006). The role of a gene cluster for trehalose metabolism in dehydration tolerance of the filamentous cyanobacterium Anabaena sp. PCC 7120. Microbiol. 152(4):979-987.

Jang IC, Oh SJ, Seo JS, Choi WB, Song SI, Kim CH, Kim YS, Seo HS, Choi YD, Nahm BH, Kim JK (2003). Expression of a bifunctional fusion of the Escherichia coli genes for trehalose-6-phosphate synthase and trehalose-6-phosphate phosphatase in transgenic rice plants increases trehalose accumulation and a biotic stress tolerance without stunting growth. Plant Physiol. 131:516-524.

Katoh H, Asthana RK, Ohmori M (2004). Gene expression in the cyanobacterium Anabaena sp. PCC 7120 under desiccation. Microb. Ecol. 47:164-174.
Leyman B, Van Dijck P, Thevelein JM (2001). An unexpected plethora of trehalose biosynthesis genes in Arabidopsis thaliana. Trends Plant Sci. 6:510-513.

Liang P, Pardee AB (1995). Recent advances in differential display. Curr. Prot. Mol. Biol. 7:274-280.

Livak KJ, Schmittgen TD (2001). Analysis of relative gene expression data using real-time quantitative PCR and the 2(-Delta Delta $\mathrm{C}(\mathrm{T})$ ) Method Meth. 25:402-408.

Martı'nez-Barajas E, Delatte T, Schluepmann H, Jong G, Nunes SC, Primavesi LF, Coello P, Mitchell RAC, Paul MJ (2011). Wheat Grain Development Is Characterized by Remarkable Trehalose 6Phosphate Accumulation Pregrain Filling: Tissue distribution and relationship to SNF1-Related Protein Kinase1 Activity. Plant Physiol. 156(1):373-381.

Mellor RB (1992). Is trehalose a symbiotic determinant in symbioses between higher plants and microorganisms? Symbiosis 12:113-129.

Mitchell RAC, CastellsBrooke N, Taubert J, Verrier PJ, Leader DJ, Rawl ings CJ (2007). Wheat estimated transcript server (WhETS): a tool to provide best estimate of hexaploid wheat transcript sequence. Nucleic Acids Res. (Web Server issue) 35:W148-151.

Müller J, Aeschbacher RA, Wingler A, Boller T, Wiemken A (2001). Trehalose and trehalase in Arabidopsis. Plant Physiol. 125:10861093.

Müller J, Staehelin C, Mellor R, Boller T, Wiemken A (1992). Partial purification and characterization of trehalose from soybean nodules, J. Plant Physiol. 140:8-13.

Murphy D, Carter D (1990). Vasopressin gene expression in the rodent hypothalamus: transcriptional and posttranscriptional responses to physiological stimulation. Mol. Endocrinol. 4(7):1051-1059.

Ozturk NZ, Talame V, Michalowski CB, Gozukirmizi N, Tuberosa R and Bohnert HJ, (2002). Monitoring large-scale changed in transcript abundance in drought-and salty-stressed barley. Plant Mol. Biol. 48:551-573.

Paul M, Pellny T, Goddijn O (2001). Enhancing photosynthesis with sugar signals. Trends Plant Sci. 6(5):197-200.

Penna S (2003). Building stress tolerance through over-producing trehalose in transgenic plants. Trends Plant Sci. 8:355-357.

Potts M (1994). Desiccation tolerance of prokaryotes. Microbiol. Rev. 58:755-805.

Pramanik MH, Imai R (2005). Functional identification of a trehalose 6phosphate phosphatase gene that is involved in transient induction of trehalose biosynthesis during chilling stress in rice. Plant Mol. Biol. 58:751-762.

Saitou N, Nei M (1987). The neighbor-joining method: a new method for reconstructing phylogenetic trees. Mol. Biol. Evol. 4:406-425.

Sambrook J, Fritisch EF, Maniatis T (1989). Molecularc loning: a laboratory manual, $2_{\text {nd }}$ ed. Cold Spring Harbor Laboratory Press.

Sanger F, Nicklen S, Coulson AR (1977). Biochemistry DNA sequencing with chain-terminating inhibitors (DNA polymerase/nucleotide sequences/bacteriophage 4X174). Proc. Nati. Acad. Sci. 74(12):5463-5467.

Satoh-Nagasawa N, Nagasawa N, Malcomber S, Sakai H, Jackson D (2006). A trehalose metabolic enzyme controls inflorescence architecture in maize. Nature 441:227-230.

Schluepmann H, Pellny T, Van Dijken A, Smeekens S, Paul M (2003). Trehalose 6-phosphate is indispensable for carbohydrate utilization and growth in Arabidopsis thaliana. Proc. Natl. Acad. Sci. USA 100:6849-6854.

Schluepmann H, Van Dijken A, Aghdasi M, Wobbes B, Paul M, Smeekens S (2004). Trehalose mediated growth inhibition of Arabidopsis seedlings is due to trehalose-6-phosphate accumulation. Plant Physiol. 135:879-890.

Shima S, Matsui H, Tahara S, Imai R (2007). Biochemical characterization of rice trehalose-6-phosphate phosphatases supports distinctive functions of these plant enzymes. FEBS J. 274:1192-1201.

Shinozaki K, Yamaguchi-Shinozaki K (2007). Gene networks involved in drought stress response and tolerance. J. Exp. Bot. 58:221-227.

Strom AR, Kaasen I (1993). Trehalose metabolism in Escherichia coli: stress protection and stress regulation of gene expression. Mol. Microbiol. 8:205-210.

Talame V, Ozturk NZ, Bohnert HJ, Tuberosa R (2006). Barley transcript 
profiles under dehydration shock and drought stress treatments: a comparative analysis. J. Exp. Botany Integr. Approaches Sustain Improve Plant Prod. Drought Stress Special Issue. pp. 1-12.

Vandercammen A, Francois J, Hers HG (1989). Characterization of trehalose-6-phosphate synthase and trehalose-6-phosphate phosphatase of Saccharomyces cerevisiae. Eur. J. Biochem. 182:613-620.

Van Dijck P, Mascorro-Gallardo JO, De Bus M, Royackers K, Iturriaga G, Thevelein JM (2002). Truncation of Arabidopsis thaliana and Selaginella lepidophylla trehalose-6-phosphate synthase unlocks high catalytic activity and supports high trehalose levels on expression in yeast. Biochem. J. 366:63-71.

Vogel G, Aeschbacher RA, Müller J, Boller T, Wiemken A (1998). Trehalose-6-phosphate phosphatases from Arabidopsis thaliana: identification by functional complementation of the yeast TPS2 mutant. Plant J. 13:673-683.
Wiemken A (1990). Trehalose in yeast, stress protectant rather than reserve carbohydrate. Antonie Van Leeuwenhoek 58:209-217.

Wingler A (2001). Trehalose metabolism in Arabidopsis: occurrence of trehalose and molecular cloning and characterization of trehalose-6phosphate synthase homologues. J. Exp. Bot. 52:1817-1826.

Wolf A, Krämer R, Morbach S (2003). Three pathways for trehalose metabolism in Corynebacterium glutamicum ATCC 13032 and their significance in response to osmotic stress. Mol. Microbiol. 49:11191134.

Xue GP, McIntyre LC, Glassop D, Shorter R (2008). Use of expression analysis to dissect alterations in carbohydrate metabolism in wheat leaves during drought stres. Plant Mol. Biol. 67:197-214. 